\title{
DIFFERENCES BETWEEN TRADITIONAL AND AUGMENTED REALITY TEACHING
}

\author{
Eva García Albaladejo, Alba Gilabert Cerdá, Asunción Lledó Carreres, \\ Gonzalo Lorenzo Lledó, Alejandro Lorenzo Lledó, \& Elena Pérez Vázquez \\ Department of Evolutionary Psychology and Didactics, University of Alicante (Spain)
}

\begin{abstract}
Nowadays, we are faced with the constant development of a technological revolution. As a result, new paradigms are emerging in education that pose new challenges for schools that need to move in the same direction as society does. In this sense, the so-called traditional method is being replaced by new teaching methodologies that are characterized by the use of technological tools with the aim of achieving a more complete knowledge and personalized to the specific needs of students. Educational institutions include these changes, since they expect an improvement in student motivation and, as a consequence, an increase in academic performance. After studying the results of different studies, there is no doubt that the inclusion of new technologies is responding to the demands in education. One of the technologies used in education that has acquired a great boom in recent years is Augmented Reality (AR). This tool is being progressively incorporated as one of the emerging technologies with the most future projection. In this line, the real change is located in the school that defines the AR with characteristics such as efficiency, innovation and creativity. The aim of this study is to explain the differences between the traditional method used in school and teaching through the Augmented Reality of 21 st century education. The results obtained show improvements in the teaching-learning process in the students according to the adaptability to the different learning difficulties of the students, changes in the organization and methodology of the classroom and, finally, the need to train teachers in all stages of education in information and communication technologies, specifically in the AR.
\end{abstract}

Keywords: Augmented reality, technologies, didactics, teaching, learning.

\section{Introduction}

To begin to contextualize the theoretical development of this study, it is essential to emphasize that, as Rodríguez Cavazos (2013) points out, through the emergence of the school as an institution in the eighteenth century and thanks to the classification of pedagogy as a science in the nineteenth century, it germinated traditional pedagogy. Its teaching method is essentially expository, its learning is evaluated by means of reproduction, the result is the main axis of the qualification, the teacher and the student are linked through an authoritarian relationship and it also conceives the student body as a mere recipient of knowledge. Likewise, the traditional method is characterized by understanding knowledge as unique, certain and objective, which can be transmitted without taking into account the context and the participation of the students (Sarmiento Santana, 2007).

On the other hand, as Pedró (2009) states, nowadays technology is a fundamental part of the life of the learners because their lifestyles are linked to the use of devices in different areas such as, among others, leisure time, interpersonal communications and social interaction. Within this framework, it is known that in recent years the advance of technologies has been of such magnitude that it has caused a general change in social behavior, increasingly associating people with technological devices. The world as it is known today would not be possible without the use of technology in most areas of life.

For this reason, in recent years, the need has been observed to replace the traditional method used in the classroom with other forms of work that help to promote the integration of students in the educational process, varying the forms of evaluation and qualification, giving knowledge the category of variable with the ability to adapt to a specific context. In this regard, in the new scenario of society, technology is exposed as a new style to approach learning and the organization of teaching, being viable to synthesize and face the problems obtaining new solutions, facilitating the teaching-learning processes and, at the same time, helping to vary the routine and the gap of the teacher training programs (Sarmiento Santana, 2007). 
In this sense, it is also important to consider that the integration of technologies in centers and classrooms has been possible because they help the school system to adapt to the particularities of the information society, preparing students to face the new digital cultural forms, improving and increasing the quality of the development of teaching and, equally, promoting the innovation of teaching materials and methods (Moreira, 2002). However, it is also necessary to set out Amar's (2006) vision, which explains that the purpose of the use of technological tools in the educational field should be to seek an application in this field with the aim of training citizens with the ability to integrate into today's society with autonomy and critical capacity, avoiding the use of new technologies as substitutes for traditional resources.

Following this line, as it is indicated by Gilabert, Pérez, Lorenzo A., Lledó and Lorenzo G. (2019), one of the methodologies that is best responding to the contemporary needs of education is the introduction of Information and Communication Technologies and, specifically, in recent decades, Augmented Reality (AR) is one of the newest trends, since it is conceived as an interactive system that superimposes artificial images generated by a processor on the real world and whose purpose is to access information by making digitally processed data available to people in real time (Cubillo, Martín, Castro and Colmenar, 2014).

Finally, Augmented Reality is one of the technologies that will endure over time because new ideas and applications appear almost daily, and, similarly, although it can already be considered a sufficiently mature tool to be used in the educational field, innovative developments in AR will promote a new generation of applications that will extend the possibilities of this technological tool (Prendes Espinosa, 2015).

\section{Objectives}

The main objective of this study is to analyze the differences between the use of the traditional method and the use of a methodology based on Augmented Reality. Starting from the main objective, several specific objectives have been developed to be achieved with the development of this work:

- To specify the characteristics of the traditional methodology and that of Augmented Reality

- To detail the benefits and limitations of these two methodologies

- To promote the advantages of using Augmented Reality as a tool in the teaching-learning process

- To enhance the use of Augmented Reality as a learning method

\section{Methods}

The present research has been based on a qualitative design within an exploratory-descriptive level. This design makes it possible to identify and describe the characteristics or phenomena with the aim of generating or inducing knowledge (Bisquerra, 2009). Specifically, this project identifies the characteristics, benefits and limitations of the traditional method, as well as of Augmented Reality. Likewise, and after the presentation of the results obtained, an analysis of the discrepancies observed between traditional teaching and the use of Augmented Reality as a methodological tool in educational centers has been carried out.

This study has been developed thanks to the collaboration of all the members of the research group of the University of Alicante IncluTic (VIRGROB-321).

\subsection{Participants}

The sample is made up of a variety of articles related to the traditional method and Augmented Reality obtained after a search and selection of articles during the month of September 2019. The Web of Science and Scopus databases have been used to search for documents.

\subsection{Design and process}

The phases of the search process have been the following:

- Phase 1. Firstly, with the aim of selecting the articles related to the traditional method and to Augmented Reality, a search was carried out in the Web of Sciences and Scopus databases.

- Phase 2. Subsequently, a compilation has been made, in a summary table, of the characteristic data, benefits and limitations of both the traditional method and Augmented Reality included in the articles selected after the search carried out.

- Phase 3. In this final phase, an analysis of the data used to complete the table of the previous phase has been carried out, in order to be able to elucidate the dissimilarities existing between the use of the traditional method and the use of a methodology based on Augmented Reality. 


\section{Results}

The search carried out has given rise to a series of articles related to the use of the traditional method in the classroom and the use of Augmented Reality as an innovative methodology in the development of the teaching-learning process, from which the qualities, advantages and disadvantages of each have been extracted. As can be seen in table 1, the data obtained have been collected and organized in different columns to facilitate subsequent data analysis.

Table 1. Characteristics, benefits and limitations of the traditional method and Augmented Reality

\begin{tabular}{l} 
Traditional method \\
\hline \\
\hline - The teacher acts as a mere speaker of knowledge. \\
- The students are conceived as a passive element and \\
receptor of the information. \\
- The relationship between teacher and student is \\
authoritarian, the teacher is the central figure. \\
- They evaluate by reproducing the curricular contents \\
that are memorized by the students in mechanical \\
way. \\
- It understands knowledge as unique, true and \\
objective. \\
- The main type of reasoning that this educational \\
method represents is deduction. \\
- It disaggregates the practice of theory into the \\
teaching-learning process. \\
- Theory always takes priority over action or \\
experience in this teaching method. \\
- It understands that knowledge can be transmitted \\
independently of the context in which learners find \\
themselves. \\
- Reason is given more importance than emotion, \\
postponing emotional development. \\
- It is developed from the book as the main \\
educational resource. \\
\hline
\end{tabular}

- The teacher acts as a guide in the students' learning.
- The students are conceived as participants and actives in the teaching-learning process.

- The relationship between the teacher and the student is egalitarian, the teachers and the students are similar.

- It evaluates through the application of the knowledge acquired and internalized by the students through its use and experimentation.

- It understands knowledge as plural and subject to be complemented and expanded.

- The type of reasoning mainly used with this methodological tool is induction.

- It associates practice and theory as a common methodological set.

- Action, experience and theory are conceived as egalitarian pillars of knowledge.

- It understands that knowledge must be transmitted taking into account the context of the students.

- More importance is given to reason than to emotion, postponing affective development.

- The resources used are made up of fictitious images, 3D models, texts or other types of digital information superimposed on real images.

- Students are not only exposed to the content, but can create it, thus expanding the real educational world.

- It expands the opportunities for learning in different contexts.

- It adapts to the learning difficulties presented by learners.

- It promotes structures of solidarity, collaborative or cooperative work.

- It enables dynamism, creativity and interaction of the resources used.

- It promotes the intrinsic motivation of the students.

- It helps the development of social skills such as collaboration, interpersonal relations and negotiation.

- It contributes to the acquisition of lasting learning. personal effort and self-discipline.

- It contributes to the improvement of memory processes among students.

- It makes possible the joint formation of several students at the same time, saving in the amount of educational resources.

- The sequence of the knowledge worked on is simple.
- It allows the combination of the real world and with elements of the virtual world, thus forming a more complete image.

- The information that it is processed visually is directly related to the content worked on.

- As it is interactive in real time, it allows any response, change or action made by the user to have an immediate impact on the scenario composed by Augmented Reality.

- It provides a more realistic experience since the information obtains the physical capacity of its environment and it is possible to interact with it.

- It enables students to have more complete experiences that would not be possible without the use of Augmented Reality.

- It encourages spatial reasoning and the acquisition of physical skills.

- It promotes an education open to knowledge. 


\begin{tabular}{|c|c|}
\hline \multicolumn{2}{|c|}{ Limitations } \\
\hline $\begin{array}{l}\text { - It promotes lack of motivation and disinterest on the } \\
\text { part of the student body which generates distraction } \\
\text { and boredom in students. } \\
\text { - It can help to slow down social development. } \\
\text { - It does not use the structure of solidarity, } \\
\text { collaborative or cooperative work and, likewise, it } \\
\text { stimulates competition and comparison among } \\
\text { students. } \\
\text { - It does not encourage curiosity, participation, } \\
\text { initiative and creativity. } \\
\text { - The presence of the teacher can impose on the } \\
\text { students in front of the group. } \\
\text { - It may lead to an inadequate adoption of information } \\
\text { or to momentary learning, since much of the } \\
\text { knowledge acquired through memorization and } \\
\text { repetition is often forgotten over time. } \\
\text { - Neither the affectivity of the students nor their } \\
\text { emotional development is taken into account. } \\
\text { - The teachers may not be well prepared to control a } \\
\text { group or to transmit the teaching correctly. } \\
\text { - It contributes to a lack of critical attitude and to the } \\
\text { passivity of the students. }\end{array}$ & $\begin{array}{l}\text { - Teachers have a lack of preparation and knowledge } \\
\text { about the tool of Augmented Reality, so it is } \\
\text { necessary to train teachers in this area. } \\
\text { - Internet accessibility and the availability of mobile } \\
\text { devices or tablets are required. } \\
\text { - It requires extra planning on the part of the teaching } \\
\text { staff. } \\
\text { - It needs a state investment to fight the digital gap } \\
\text { between students. }\end{array}$ \\
\hline
\end{tabular}

\section{Conclusions}

After the analysis of the results obtained, it is observed that the properties that characterize traditional teaching are very different from the characteristics noticed in a methodology that uses Augmented Reality as the main tool in the teaching-learning process.

Specifically in relation to the benefits provided by each of the two methods analyzed, it can be stated that the number of advantages provided by a methodology based on the use of AR is much greater than the amount obtained in the traditional method. Likewise, the benefits of AR are better suited to the needs of today's students who are developing in a technological society and who use all types of devices in their daily lives.

Similarly, with respect to the limitations, it should be noted that the disadvantages found in the methodology based on Augmented Reality are fewer than those observed in the traditional method, because the latter method, for example, puts barriers to social and communicative development of students and delimits knowledge.

For all the above reasons, it can be concluded that a methodology based on Augmented Reality provides more benefits and fewer limitations than the traditional method. In this sense, it is possible to determine that if more economic and temporary resources were invested in the development of methodologies based on AR, it would be possible to achieve the acquisition by students of a more lasting knowledge, promote social relations of students, stimulate creativity and involvement of students in the teaching-learning process and, thus, increase their motivation, and expand knowledge capabilities, among other benefits provided by this methodological tool.

Finally, it is important to specify that, throughout this study, it has been demonstrated that the proposed objectives have been met, as the differences between the use of the traditional method and the use of a methodology based on Augmented Reality have been analyzed by exposing the characteristics and presenting the benefits and limitations of the two types of teaching methods. Likewise, through the development of this study it has been possible to promote the advantages of the use of AR as a tool in the teaching-learning process and to enhance the use of AR as a learning methodology.

\section{References}

Amar, V. (2006). Planteamientos críticos de las nuevas tecnologías aplicadas a la educación en la sociedad de la información y de la comunicación. Pixel-Bit. Revista de Medios y Educación, 27, 79-87.

Bisquerra, R. (Coord.) (2009). Metodolog a de la investigaci $n$ educativa. (2a ed). Madrid, España: La Muralla.

Cirigliano, G. F. J., \& Villaverde, A. (1968). Dinámica de grupos y educación: fundamentos y técnicas.

Cubillo, J., Martín, S., Castro, M., \& Colmenar, A. (2014). Recursos digitales autónomos mediante realidad aumentada. RIED. Revista Iberoamericana de Educación a Distancia, 17(2), 241-274. 
De la Horra Villacé, I. (2017). Realidad aumentada, una revolución educativa. EDMETIC, 6(1), 9-22. doi: https://doi.org/10.21071/edmetic.vói1.5762

Díaz, B. (2017). La escuela tradicional y la Escuela Nueva: análisis desde la pedagogía crítica (Doctoral dissertation, Tesis de pregrado). Bogotá, Colombia: Universidad Pedagógica Nacional. http://200.23.113.51/pdf/33326.pdf

Gavilanes, W., Abásolo Guerrero, M. J., \& Cuji, B. (2018). Resumen de revisiones sobre Realidad Aumentada en Educación. Revista Espacios, 39(15).

Gilabert, A., Pérez, E., Lorenzo, A., Lledó, A., \& Lorenzo, G. (2019). La realidad aumentada en la intervención del alumnado con trastorno del espectro autista a través de la producción científica. Revista INFAD de Psicología. International Journal of Developmental and Educational Psychology, 3(1), 595-606. doi: https://doi.org/10.17060/ijodaep.2019.n1.v3.1639

Moreira, M. A. (2002). La integración escolar de las nuevas tecnologías. Entre el deseo y la realidad. Revista del Fórum Europeo de Administradores de la Educación, 10(6), 14-18.

Ortiz Ocaña, A. L., Reales Cervantes, J. P., \& Rubio Hernández, B. I. (2014). Ontología y episteme de los modelos pedagógicos. Revista Educación En Ingeniería, 9(18), 23-34. doi: https://doi.org/10.26 507/rei.v9n18.396

Pedró, F. (2009, September). New Millennium learners in higher education: Evidence and policy implications. Paper presented at the International Conference on 21 st Century Competencies, Brussels: OECD/CERI.

Prendes Espinosa, C. (2015). Realidad aumentada y educación: análisis de experiencias prácticas. Píxel-Bit. Revista de Medios y Educación, 46, 187-203. doi: https://doi.org/10.12795/pixel bit.2015.i46.12

Rodríguez Cavazos, J. (2013). Una mirada a la pedagogía tradicional y humanista. Presencia universitaria, 3(5), 36-45.

Sarmiento Santana, M. (2007). La enseñanza de las matemáticas y las Ntic. Una estrategia de formación permanente. Universitat Rovira i Virgili.

Soto, B. (2011). Ventajas y desventajas de la Realidad Aumentada a la hora de diseñar ambientes de aprendizaje. America Learning y Media, 5. 